\title{
THE EFFECT OF PROBLEM-BASED PRACTICE TOWARDS LEARNING OUTCOME AND PROCESS SKILL ON CELL MATERIAL
}

\author{
Viqi Novita*, Meida Nugrahalia \\ Program Studi Pendidikan Biologi, FMIPA, Universitas Negeri Medan, Jl. Willem Iskandar Psr. V Medan Estate, \\ Medan, Indonesia, 20221 \\ *Korespondensi Author: viqinovita25@gmail.com
}

\section{INFO ARTIKEL}

Histori Artikel

Received 7 November 2018

Revised 26 Maret 2020

Accepted 26 Maret 2020

Published 2 April 2020

Keywords:

Learning Outcome, Problem Based Practice, Scientific Process Skill

\begin{abstract}
ABSTRAK
Penelitian ini bertujuan untuk mengetahui pengaruh praktikum berbasis masalah terhadap hasil belajar dan keterampilan proses siswa pada materi sel kelas XI IPA SMA Swasta Kartika 1-2 T.P 2018/2019. Penelitian ini dilaksanakan pada bulan Juli-September, di SMA Kartika 1-2 Medan. Populasi penelitian adalah seluruh siswa kelas XI IPA sebanyak 179 orang. Sampel diambil secara acak dan berjumlah 72 orang. Hasil uji statistik menunjukkan bahwa rata-rata hasil belajar siswa pada kelas eksperimen adalah pretes sebesar 63,22 dan postes sebesar 82,89, sedangkan kelas kontrol pretes sebesar 59,55 dan postes sebesar 69,44. Selanjutnya uji hipotesis (uji t) menunjukkan bahwa (thitung $=5,4561>$ ttabel $=1,997$ ). Pelaksanaan praktikum berbasis masalah dapat meningkatkan keterampilan proses siswa. Hal ini ditunjukkan pada hasil lembar pengamatan kelas eksperimen memiliki rata-rata keterampilan proses pada kategori "Tinggi" sedangkan pada kelas kontrol rata-rata keterampilan proses hanya sampai kategori "Sedang". Dapat disimpulkan bahwa praktikum berbasis masalah berpengaruh signifikan terhadap hasil belajar dan keterampilan proses siswa kelas XI SMA Swasta Kartika 1-2 Medan T.P 2018/2019.
\end{abstract}

\section{ABSTRACT}

This study aims to determine the effect of problem-based practice on student learning outcome and process skill in cell material in class XI Science Kartika Private High School 1-2 T.P 2018/2019. This research was conducted in JulySeptember, at SMA Kartika 1-2 Medan. The population of this study was all students of class XI as many as 179 people. Samples are taken randomly. There were as many as 72 students. Statistical analysis showed that the average student learning outcomes in the experimental class are pretest of 63.22 and posttest of 82.89 , while the control class pretest is 59.55 and the posttest is 69.44 . Then hypothesis test (t-test) showed that (tcount $=5.4561$ $>$ ttable $=1.997)$. Which is means that the problem-based practice has a significant effect on the learning outcome. Besides, practice using PBL models can improve student process skills. This is shown in the results of the experimental class observation sheet having an average process skill in the "High" category. Whereas in the control class the average process skill is only up to the "Medium" category. So it can be concluded that the Problem-based practice has a significant effect on the learning outcome and process skill of class XI students of Private Kartika Senior High School 1-2 Medan T.P 2018/2019.

Copyright (C) 2019 Universitas Negeri Medan. Artikel Open Access dibawah lisensi CCBY-4.0 (https://creativecommons.org/licenses/by/4.0) 


\section{How To Cite:}

Novita, V., Nugrahalia, M. (2020). The Effect of Problem-Based Practice Towards Learning Outcome and Process Skill on Cell Material. Jurnal Pelita Pendidikan, 8(1), 027-033.

\section{PENDAHULUAN}

Di era modern pendidikan merupakan salah satu tuntutan dan kewajiban yang harus diikutsertakan dalam kehidupan sehari-hari. Hazriani (2012) menyatakan bahwa pendidikan merupakan suatu wadah yang berisi kegiatan belajar mengajar. Selain pendidikan dapat diartikan sebagai suatu rangkaian interaksi antara peserta didik dan guru dalam rangka mencapai hasil dan tujuan pembelajaran. Pembelajaran dapat meliputi kegiatan belajar mengajar di dalam kelas dan kegiatan praktikum di laboratorium.

Namun terdapat masalah utama dalam pembelajaran pada pendidikan formal, masalah tersebut adalah masih rendahnya daya serap peserta didik yang tampak dari hasil belajar peserta didik yang senantiasa memprihatinkan. berdasarkan hasil observasi awal yang telah dilakukan pada bulan Januari 2018 di SMA Swasta Kartika 1-2 Medan, diperoleh data bahwa rata-rata nilai hasil belajar biologi pada semester genap tahun 2017/2018 masih belum memenuhi standar ketuntasan. Skor kriteria ketuntasan maksimum dengan nilai 76.

Berdasarkan wawancara penulis yang telah dilakukan kepada guru bidang studi biologi kelas XI, diperoleh informasi bahwa perlu dilakukan pendalaman praktikum pada pembelajaran biologi yang sesuai dengan standar indikator. Berdasarkan silabus biologi SMA, seharusnya pelaksanaan praktikum pada semester ganjil tercatat sebanyak empat kali. Namun praktikum tidak dilaksanakan secara efektif. Faktor penghambat pelaksanaan praktikum ialah minimnya sarana dan prasarana laboratorium serta adanya perubahan fungsi ruang laboratorium menjadi ruang kelas. Selain itu diperlukan keaktifan peran guru pada pelaksanaan praktikum tersebut.

Berdasarkan Permendikbud No. 22 Tahun 2016 tentang standar proses diperoleh informasi bahwa penerapan pendekaan saintifik belum sesuai dengan tahapannya. Proses pembelajaran masih sampai pada tahap mengamatisehingga keaktifan siswa cenderung pasif. Siswa kurang berpartisipasi aktif dalam bertanya dan mengajukan pendapat pada saat proses kegiatan belajar mengajar. Siswa cenderung bergantung pada guru untuk mendapatkan materi pelajaran. Oleh karena itu, diperlukan aplikasi pembelajaran yang menyenangkan yang dapat memberikan motivasi dan dukungan belajar kepada siswa.

Di SMA Swasta Kartika 1-2, masih ditemukan beberapa permasalahan, penelitian ini dilakukan untuk mengurangi permasalahan melalui kegiatan praktikum berbasis masalah pada materi sel. Pemilihan materi sel karena pada materi sel terdapat submateri berupa transpor zat melewati membran sel yang terdiri atas difusi, osmosis, transpor aktif, serta endositosis dan ektositosis. Dari keempat subjudul tersebut dapat dijadikan sebagai sumber masalah yang sederhana bagi setiap siswa. Selain itu, Sanjaya (2012) menyatakan bahwa model pembelajaran berbasis masalah (PBM) dapat diartikan sebagai rangkaian aktivitas pembelajaran yang menekankan kepada proses penyelesaian masalah secara ilmiah.

Hasil penelitian Nafiah (2014)mengungkapkan bahwa model Problem Based Learning (PBL) dapat meningkatkan keterampilan berpikir kritis dan hasil belajar siswa. -i Mmenurut Efendi, dkk, (2013) pelaksanaan praktikum biologi dapat meningkatkan kemampuan pemahaman konsep dan penalaran logis matematis siswa. Hasil penelitian Noviar dan Hastuti (2015) menunjukkan bahwa PBM berbasis pendekatan saintifik secara signifikan meningkatkan hasil belajar biologi pada ranah kognitif, afektif dan psikomotrik siswa.

Penelitian ini -bertujuan untuk mengetahui pengaruh kegiatan praktikum berbasis masalah terhadap hasil belajar dan keterampilan proses siswa pada materi sel kelas XI IPA SMA Swasta Kartika 1-2 Medan.

\section{METODE PENELITIAN}

Penelitian ini telah dilakukan di SMA Kartika 12, Jl. Brigjend H.A Manaf Lubis, Helvetia Tengah, Medan, Penelitian dilakukan pada bulan Juli September 2018. Populasi pada penelitian ini adalah seluruh siswa kelas XI SMA Swasta Kartika 12 Medan Tahun Pembelajaran 2018/2019 yang 
terdiri dari 5 kelas IPA. Teknik sampling acak yang digunakan berjenis simple random sampling yaitu pemilihan elemen populasi yang dilakukan sedemikian rupa sehingga setiap elemen tersebut mempunyai kesempatan yang sama untuk terpilih.

Jenis Penelitian ini adalah quasi eksperimen. Quasi eksperimen adalah suatu jenis eksperimen yang menyadari bahwa kontrol secara tradisional tidak dapat dilakukan secara tuntas. Desain penelitian ini adalah desain pretes dan postes. Pretes, dilaksanakan sebelum mengadakan kegiatan praktikum yang bertujuan untuk mengetahui kemampuan awal siswa tentang materi pelajaran. Postes, dilaksanakan setelah kegiatan praktikum. Hal tersebut bertujuan untuk mengetahui ketercapaian hasil pengajaran yang diperoleh siswa.

Tahapan pada penelitian meliputi 3 tahapan yakni tahap persiapan, tahap pelaksanaan dan tahap akhir penelitian. Tahap persiapan penelitian meliputi: dirumuskan masalah yang akan diteliti oleh penulis, dicari studi literatur mengenai model PBM, disusun proposal penelitian yang berisikan masalah yang akan diteliti, variabel, sumber data, instrumen penelitian yang digunakan serta langkahlangkah penelitan yang akan diteliti. Selama penyusunan juga dilakukan pra-penelitian terhadap subjek yang akan diteliti dalam memperoleh data yang relevan, dilaksanakan seminar proposal, disusun instrumen penelitian dan RPP (Rencana Pelaksanaan Pembelajaran), selanjutnya dilakukan uji coba instrumen tersebut. Tahap pelaksanaan penelitan terdiri atas beberapa tahapan, yakni: dilaksanakan proses kegiatan praktikum berbasis masalah pada kelas eksperimen, sedangkan pada kelas kontrol menggunakan model konvensional, diamati sikap siswa dengan acuan lembar observasi, diberikan pretes dan postes berupa soal yang sama pada kelas kontrol dan kelas eksperimen. Pada tahap akhir yang dilakukan diantaranya: dianalisis dan dilakukan pengolahan data yang diperoleh saat penelitian, pada hasil penelitian, dibuat laporan akhir terhadap penelitian, hasil penelitian dipresentasikan.

Sebelum penelitian ini dilaksanakan, terlebih dahulu penulis melakukan tahap pengujian instrumen - kepada validator ahli. Validator ahli yang diperlukan sebanyak dua orang. Validator I berfungsi untuk memvalidkan tingkat kesukaran atau tingkat kognitif soal. Sedangkan validator II berfungsi untuk memvalidkan kesesuaian soal dengan kompetensi dasar dan indikator pembelajaran. Teknik Analisis Data berupa Uji normalitas, Uji homogenitas, Uji hipotesis (Uji t).

\section{HASIL DAN PEMBAHASAN}

Hasil analisis keterampilan proses ini ditunjukkan pada hasil lembar pengamatan. Lembar pengamatan meliputi lembar untuk kelas eksperimen dan kelas kontrol. Berdasarkan hasil akumulasi data keterampilan proses dapat dikonversikan pada bentuk data dengan KKM. Data nilai tersebut dapat dilihat pada Tabel 1.

Tabel 1. Konversi Nilai Keterampilan Proses Siswa Pada Setiap Indikator Kelas Eksperimen dan Kelas Kontrol

\begin{tabular}{lccccc}
\hline \multirow{2}{*}{ Kelas } & \multicolumn{5}{c}{ Keterampilan Proses } \\
\cline { 2 - 6 } & $\begin{array}{c}\text { Merumuskan } \\
\text { masalah }\end{array}$ & $\begin{array}{c}\text { Merumuskan } \\
\text { hipotesis }\end{array}$ & $\begin{array}{c}\text { Merancang keg. } \\
\text { praktikum }\end{array}$ & $\begin{array}{c}\text { Melaksanakan } \\
\text { praktikum }\end{array}$ & $\begin{array}{c}\text { Menganalisis } \\
\text { data }\end{array}$ \\
\hline Eksperimen & 65,2 & 50 & 82,5 & 82,5 & 90 \\
Kontrol & 45 & 50 & 57,5 & 65 & 79 \\
\hline
\end{tabular}




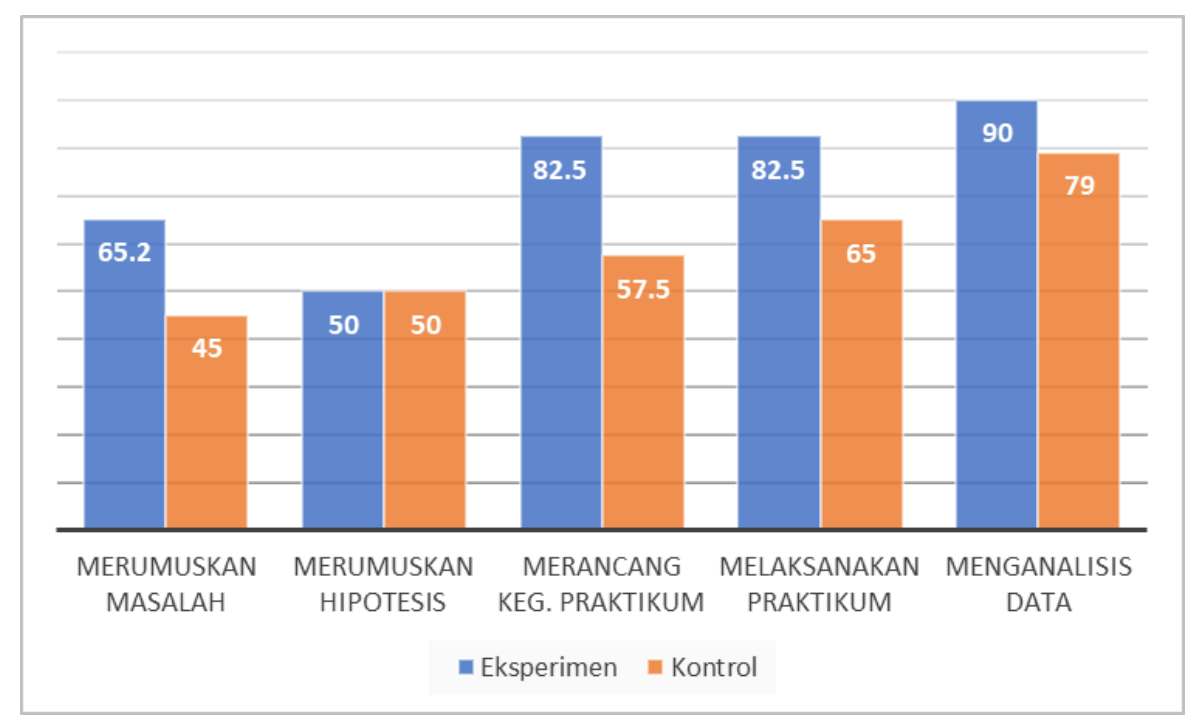

Gambar 1. Histogram Nilai Rata-Rata Keterampilan Proses Siswa Pada Setiap Indikator Kelas Eksperimen dan Kelas Kontrol

Berdasarkan data yang didapatkan pada pengamatan kelas eksperimen rata-rata keterampilan proses terletak pada kategori "Tinggi" dengan frekuensi sebesar $66,67 \%$. Sedangkan pada kelas kontrol rata-rata keterampilan proses hanya sampai kategori "Sedang" sebesar 83,3\%.

Hasil belajar peserta didik yang telah diperoleh berupa hasil belajar kelas eksperimen dan hasil belajar kelas kontrol. Selanjutnya dapat dianalisis untuk menguji hipotesis dengan menggunakan rumus uji t. Selain menguji hipotesis, tahap awal dilakukan uji persyaratan analisis data uji normalitas dan uji homogenitas data dengan terlebih yaitu dahulu menghitung rata- rata, standar deviasi dan varians dari kedua kelas. Berdasarkan nilai hasil belajar tersebut, maka diperoleh data hasil belajar pada Tabel 2. di bawah ini.

Tabel 2. Data Hasil Belajar Siswa

\begin{tabular}{lcccc}
\hline \multirow{2}{*}{ Ket } & \multicolumn{2}{c}{ Eksperimen } & \multicolumn{2}{c}{ Kontrol } \\
\cline { 2 - 5 } & Pretes & Postes & Pretes & Postes \\
\hline Rata-rata & 63,22 & 82,88 & 59,55 & 69,44 \\
\hline Standar Deviasi & 13,71 & 9,39 & 13,18 & 11,43 \\
\hline Varians & 187,69 & 88,32 & 173,96 & 130,64 \\
\hline
\end{tabular}

Uji normalitas data hasil belajar dilakukan dengan menggunakan uji liliefors. Pengujian normalitas dilakukan dengan tujuan untuk mengetahui data berasal dari sampel yang normal atau tidak. Berdasarkan hasil perhitungan, diperoleh diperoleh $L_{\text {tabel }}$ lebih besar dari Lo pada $\alpha=0,05 ; \mathrm{db}=5 \%$ yaitu 0,1253 . Hal ini dapat disimpulkan bahwa data nilai statistik siswa di atas berdistribusi normal. Uji homogenitas pada setiap sampel, diperoleh Fhitung < Ftabel. Perhitungan pretes untuk kelas eksperimen dan kontrol di peroleh Fhitung $=1,0788<$ Ftabel $=1,965$. Perhitungan postes untuk kelas eksperimen dan kontrol di peroleh Fhitung =1,4790 < Ftabel =1,965. Oleh karena itu dapat disimpulkan bahwa sampel memiliki varians yang sama dan homogen.

Tabel 3. Hasil Uji Hipotesis Terhadap Nilai

\begin{tabular}{lccccl}
\hline \multicolumn{1}{c}{ Kelas } & $\overline{\boldsymbol{X}}$ & $\mathbf{S}^{\mathbf{2}}$ & $\mathbf{t}_{\text {hitung }}$ & $\mathbf{t}_{\text {tabel }}$ & Ket \\
\hline Eksperimen & 82,8889 & 88,3299 & \multirow{2}{*}{5,4561} & \multirow{2}{*}{1,997} & thitung \\
Kontrol & 69,4444 & 130,6449 & & & $>t_{\text {tabel }}$ \\
\hline
\end{tabular}


Uji hipotesis menggunakan uji t dua pihak. Uji ini bertujuan untuk mengetahui hipotesis dalam penelitian ini diterima atau ditolak. Krtiteria pengujian jika t-hitung > t-tabel maka Ha diterima sedangkan $\mathrm{HO}$ ditolak. Data hasil uji hipotesis pada penelitian ini dapat dilihat pada Tabel 3.

Berdasarkan Tabel 3, sesuai dengan kriteria yang telah ditetapkan diperoleh thitung sebesar 5,4561 berada pada daerah penolakan $\mathrm{H}_{0}$ yakni $t_{\text {hitung }}>t_{\text {tabel }}$ sebesar $5,4561>1,99$. Oleh karena itu dapat disimpulkan bahwa peningkatan hasil belajar siswa kelas eksperimen lebih tinggi dari pada peningkatan hasil belajar kelas kontrol. Pelaksanaan praktikum berbasis masalah berpengaruh signifikan terhadap hasil belajar dan keterampilan proses siswa.

\section{Keterampilan Proses}

Praktikum berbasis masalah dilakukan sesuai dengan fase-fase pembelajaran berbasis masalah. Tahap awal dilakukan berupa tahap orientasi siswa terhadap suatu masalah. Siswa membentuk suatu kelompok yang bersifat heterogen. Hal ini bertujuan agar siswa yang memiliki tingkatan kognitif, afektif dan psikomotorik lebih tinggi dapat membaur dengan siswa yang tingkatan kognitif, afektif dan psikomotorik sedang bahkan rendah. Sehingga semua siswa memiliki kesempatan yang sama dalam mengembangkan keterampilan yang dimiliki. Sesuai dengan penelitian menurut Rosidah, dkk, (2014) bahwasanya pembelajaran berbasis masalah yang dilaksanakan dalam penelitian memberikan kesempatan kepada siswa untuk bekerja dan berbagi pengetahuan melalui kegiatan kelompok atau diskusi.

Tahapan praktikum berbasis masalah diantaranya pengorganisasian siswa dengan memberikan LKPD. Hal tersebut bertujuan untuk meyajikan tujuan pembelajaran, petunjuk dan cara kerja, data pengamatan, perumusan masalah dan data ilmiah yang harus dipecahkan secara bersama pada kegiatan praktikum difusi dan osmosis. Tahapan penilaian keterampilan proses siswa terdiri atas dua fase. Tahapan pertama menggunaan LKPD 1a tentang pelaksanaan praktikum materi difusi, dan tahap kedua menggunakan LKPD 2a materi pelaksanaan praktikum berbasis masalah mengenai osmosis.
Berdasaran kedua pelaksanaan praktikum yang telah dilakukan, pelaksanaan praktikum pada LKPD 1a (difusi) memiliki nilai yang lebih rendah dibandingkan LKPD 2a (osmosis). Hal ini dikarenakan pada pelaksanaan praktikum menggunakan LKPD 1a siswa masih cenderung pada fase orientasi (pengenalan). Sedangkan pada LKPD 2a siswa sudah mulai aktif dan mengetahui tahapan dan indikator dari keterampilan proses. Menurut Utomo, dkk, (2014) -LKPD dapat membangun pengetahuan siswa sendiri begitupun pengelompokan dalam belajar. Siswa dapat menyelesaikan masalah dengan banyak cara karena memungkinkan timbulnya berbagai pemikiran yang berbeda, serta proses presentasi yang dilakukan juga akan membuat siswa untuk lebih memahami lagi masalah yang ada agar penampilannya di depan kelas tidak mengecewakan. Sehingga pembelajaran berbasis masalah (PBL) berpengaruh terhadap peningkatan pemahaman konsep siswa dan hasil belajar siswa kelas VIII SMPN 1 Sumbermalang dengan rerata pretes 52,45 menjadi rerata posest 73,81 .

Kegiatan praktikum ini dilakukan untuk mengetahui tingkat keterampilan proses siswa. Materi sel dijadikan objek dikarenakan pada KD Kompetensi dasar terdapat kegiatan praktikum tentang osmosis dan difusi. Selain itu praktikum ini ditujukan untuk meningkatkan kemampuan pada tingkat kognitif, afektif serta psikomotorik siswa. Siswa juga dituntun untuk meningkatkan kreasi dan daya inovasi. Pelaksanaan praktikum yang menyenangkan dan dilakukan atas kreasi siswa secara sendirinya akan dapat meningkatkan keterampilan proses serta meningkatkan hasil belajar siswa.

Keterampilan proses tersebut terdiri dari lima indikator. Pertama, perumusan masalah sesuai dengan bacaan pendukung secara cermat dan tepat. Kedua, merumuskan hipotesis sesuai dengan rumusan masalah secara tepat dan benar. Ketiga, merancang kegiatan praktikum sesuai dengan alat dan bahan yang tersedia secara sistematis, mandiri dan kreatif. Keempat, melaksanakan kegiatan praktikum sesuai dengan rancangan secara kreatif, aktif dan tertib. Kelima menganalisis data hasil pengamatan dan menyampaikan laporan secara tepat dan jelas. 
Berdasarkan kelima Indikator tersebut, indikator yang dapat mencapai rata-rata tertinggi kelas eksperimen hanya terdiri atas 3 indikator berupa merancang praktikum, melaksanakan praktikum dan menganalisis data praktikum serta mempresentasian hasil. Hal ini dikarenakan peserta didik pada awalnya terbiasa dengan pembelajaran yang menuntun mereka bersikap pasif. Pada pembelajaran yang menuntut keaktifan, peserta didik diharuskan untuk mampu menganalisis data hasil pengamatan secara ilmiah dan mempresentasikan data yang diperoleh secara antusias dan semangat. Hazriani (2012) mengemukakan empat alasan pentingnya kegiatan praktikum dalam IPA, praktikum membangkitkan motivasi belajar siswa, praktikum mengembangkan keterampilan dasar melakukan eksperimen, praktikum menjadi wahana belajar pendekatan ilmiah, praktikum menunjang materi pelajaran yang memberikan kesempatan bagi siswa untuk menemukan teori dan membuktikan teori. Sehingga penerapan praktikum ini dapat meningkatkan keterampilan proses siswa pada kegiatan belajar mengajar pada materi sel.

Berdasarkan kelima indikator di atas, hasil yang didapatkan dari pengamatan yakni kelas eksperimen lebih menunjukkan keterampilan proses pada kategori "Tinggi" sebanyak 4 kelompok. Pada kelas kontrol nilai keterampilan proses mencapai kategori "Sedang" sebanyak 5 kelompok. Secara keseluruhan, pada indikator 1 dan 2 masih belum mencapai nilai standar KKM. Hal ini dikarenakan siswa masih pasif dalam mengeluarkan suatu pertanyaan ketika KBM berlangsung. Sedangkan ketercapaian indikator 3, 4 dan 5 sudah memenuhi nilai pada standar KKM. Hal ini perlu dilakukan perbaikan atau inovasi pembelajaran yang lebih mendukung peran siswa dalam meningkatkan nilai keterampilan proses peserta didik. Seperti halnya pada kelas eksperimen seluruh peserta didik aktif dan antusias di dalam kelompoknya masing- masing untuk melakukan praktikum. Sedangkan pada kelas kontrol masih ada beberapa anggota kelompok bersikap pasif, dan hanya beberapa orang tertentu yang melaksanakan praktikum tersebut.

\section{Hasil Belajar}

Pemecahan masalah merupakan teknik yang cukup bagus untuk lebih memahami pelajaran. Pemecahan masalah dapat menantang kemampuan siswa serta memberikan kepuasan untuk menemukan pengetahuan baru bagi siswa. Pemecahan masalah dapat meningkatkan aktivitas belajar siswa dan dapat membantu siswa bagaimana mentransfer pengetahuan mereka untuk memahami masalah dalam kehidupan nyata, serta dapat membantu siswa untuk mengembangkan pengetahuan baru dan bertanggung jawab dalam kegiatan praktikum yang mereka lakukan.

Setelah dilaksanakan praktikum menggunakan model PBL, diperoleh data bahwa hasil belajar berupa postes menunjukkan hasil yang signifikan. Peningkatan hasil belajar pretes dan postes pada kelas eksperimen dari 63,33 menjadi 82,89 . Selanjutnya peningkatan yang sama juga terjadi pada kelas kontrol dengan nilai rata-rata 59,55 menjadi 69,44. Penelitian lain oleh Abdurrozak, dkk, (2016) hasil belajar siswa kelas eksperimen dengan pembelajaran berbasis masalah (PBL) meningkat secara signifikan terhadap hasil belajar siswa. Hal tersebut dapat dilihat dari skor rata-rata postes sebanyak 8,3 lebih tinggi dibandingkan dengan hasil pretes sebanyak 6,4 .

Berdasarkan kedua data di atas, dapat dianalisis bahwa hasil belajar dari kedua kelas mengalami peningkatan. Namun peningkatan yang signifikan terjadi pada kelas eksperimen dengan menggunakan praktikum berbasis masalah. Hal tersebut dibuktikan dengan lebih banyaknya jumlah siswa yang telah lulus KKM sebanyak 30 siswa dan jumlah tidak lulus sebanyak 6 siswa. Sedangkan pada kelas kontrol jumlah siswa yang telah mencapai KKM sebanyak 13 siswa. Sesuai dengan penelitian yang telah dilakukan oleh Bungle (2014) menyimpulkan bahwa pembelajaran berasis masalah dapat meningkatkan hasil belajar siswa pada materi prisma. Hasil belajar siswa dari siklus I sebanyak 7 siswa yang lulus KKM menjadi 24 siswa yang telah mencapai KKM.

Selain itu, pada penelitian ini dilakukan tes hasil evaluasi pembelajaran. Evaluasi pembelajaran tersebut dilakukan untuk mengetahui pembelajaran yang dilaksanakan belum atau sudah 
mampu diterima oleh siswa. Berdasarkan hasil evaluasi tersebut diperoleh data bahwa hasil ratarata pada LKPD 1a sebesar 78,89. Sedangan pada LKPD 2a sebesar 79,06. Hal ini dapat disimpulkan bahwa terdapat peningkatan hasil belajar siswa pada pelaksanaan praktikum LKPD 1a dan LKPD 2a. Berdasarkan penelitian yang dilakukan oleh Nafiah (2014) menyimpulkan bahwa terdapat peningkatan hasil belajar siswa setelah penerapan pembelajaran berbasis masalah yakni sebesar 31,03\%. Jumlah siswa yang mencapai KKM pada akhir siklus II yakni sebanyak 29 siswa (100\%).

Hasil belajar akan mempengaruhi berhasil tidaknya pembelajaran yang dilakukan ketika proses belajar mengajar berlangsung. Syarifuddin (2011) mengatakan bahwa keberhasilan belajar merupakan hasil terhadap interaksi dari tindakan belajar dan tindakan mengajar. Hasil belajar dapat dilihat dari adanya suatu perubahan pada ranah kognitif, afektif dan psikomotorik., Sehingga hasil belajar yang diukur sangat tergantung kepada tujuan pendidikan. Peran guru bertujuan untuk mengupayakan hasil belajar siswa dapat terus meningkat.

\section{KESIMPULAN}

Berdasarkan hasil penelitian di atas, maka penulis dapat mengambil beberapa kesimpulan. Praktikum berbasis masalah berpengaruh signifikan terhadap peningkatan hasil belajar siswa sebesar $31 \%$ pada materi sel di kelas XI SMA Swasta Kartika 1-2 Medan T.P 2018/2019. Praktikum berbasis masalah belum berpengaruh signifikan terhadap keterampilan proses siswa pada materi sel.

\section{DAFTAR PUSTAKA}

Abdurrozak, R., \& Jayadinata, A. K. (2016). Pengaruh Model Problem Based Learning Terhadap Kemampuan Berpikir Kreatif Siswa. Jurnal Pena Ilmiah, 1(1), 871-880.

Basri, H. (2015). Paradigma Baru Sistem Pembelajaran. Pustaka Setia, Bandung.

Bungel, M. F. (2014). Penerapan model pembelajaran problem-based learning untuk meningkatkan hasil belajar siswa kelas VIII SMP Negeri 4 Palu pada materi prisma. Jurnal Elektronik Pendidikan Matematika Tadulako, 2(1).

Efendi, M. Y., Armanto, D., \& Asmin, A. Analisis Pelaksanaan Praktikum Biologi dan Upaya
Meningkatkan Pemahaman Konsep dan Penalaran Matematika dengan Menggunakan Model Pembelajaran Berbasis Masalah di SMA Negeri 2 Binjai. Tabularasa, 10(2).

Hamidah, A. (2014). Persepsi Siswa Tentang Kegiatan Praktikum Biologi di Laboratorium SMA Negeri Se-Kota Jambi. Sainmatika: Jurnal Sains dan Matematika Universitas Jambi, 8(1).

Noviar, D., \& Hastuti, D. R. (2015). Pengaruh model problem-based learning (PBL) berbasis scientific approach terhadap hasil belajar biologi siswa kelas X di SMA N 2 Banguntapan TA 2014/2015. Bioedukasi: Jurnal Pendidikan Biologi, 8(2), 42-47.

Hazriani, F. (2012). Penerapan Pembelajaran Praktikum Biologi Pada Materi Jaringan Pada Tumbuhan Untuk Menumbuhkan Keterampilan Proses Sains (KPS) Siswa Kelas XI IPA di SMA Negeri 1 Kasokandel Kabupaten Majalengka. Skripsi. Fakultas Tarbiyah IAIN Syekh Nurjati, Cirebon.

Jaya, F. (2015). Perencanaan pembelajaran, Gema Ihsan, Medan.

Nafiah, Y. N., \& Suyanto, W. (2014). Penerapan model problem-based learning untuk meningkatkan keterampilan berpikir kritis dan hasil belajar siswa. Jurnal Pendidikan Vokasi, 4(1).

Wasonowati, R. R. T., Redjeki, T., \& Ariani, S. R. D. (2014). Penerapan model problem-based learning (pbl) pada pembelajaran hukumhukum dasar kimia ditinjau dari aktivitas dan hasil belajar siswa kelas $\mathrm{x}$ ipa sma negeri 2 surakarta tahun pelajaran 2013/2014. Jurnal Pendidikan Kimia, 3(3), 66-75.

Sanjaya, W. (2012). Strategi Pembelajaran Berorientasi Standar Proses Pendidikan. Kencana Prenada Media, Jakarta.

Syarifuddin, A. (2011). Penerapan Model Pembelajaran Cooperative Belajar dan Faktor-faktor yang Mempengaruhi: TA'DIB.

Utomo, T., Wahyuni, D., \& Hariyadi, S. (2014). Pengaruh Model Pembelajaran Berbasis Masalah (Problem Based Learning) Terhadap Pemahaman Konsep dan Kemampuan Berpikir Kreatif Siswa (Siswa Kelas VIII Semester Gasal SMPN 1 Sumbermalang Kabupaten Situbondo Tahun Ajaran 2012/2013). Jurnal Edukasi, 1(1), 5-9. 